\title{
Organic farming and social context: A challenge for us all
}

\author{
Laura B. DeLind
}

The value of organic and low-chemical agriculture has become increasingly apparent to many small and family-scale farmers over the last decade. Such practices regenerate the soil, reduce environmental pollution, lower production costs, and produce quality foods that can be sold at a premium. Thus, for many growers, alternative farm methods appear to combine the best of two worlds - a reliable way to make a living and a responsible way to produce good food. Yet, bound as they are to the conventional, market-based production paradigm, this reliability and responsibility may be more imagined than real.

How can this be? To begin, an exclusive or premium product requires an exclusive or specialized market. One Michigan farmer, for example, chose to advertise his organic beef by claiming that he raised the same cattle in the same manner as those raised for the Queen of England's table. The implication was clear: for a price, we all can eat like queens. While this particular promotional ploy may be extreme, such a marketing strategy is not uncommon. But it offers little sustained opportunity for the smaller alternative producer. With sales dependent on a circumscribed target population, a specialty market can quickly collapse because of a change in vogue, in transportation costs, or in relationships among wholesalers or retailers. Likewise, the necessity of competing with other nontraditional farmers for a market niche and maintaining a competitive edge within it

Laura B. DeLind is Senior Academic Specialist, Department of Anthropology, Michigan State University, East Lansing, MI 48824. requires expanding one's production and marketing options or further differentiating one's products. Both options threaten to increase dependency or reduce flexibility by increasing the scale of operations and capital investment and by narrowing the range of processes and products that can be managed profitably. Capital efficiency again is positioned to replace ecological rationality.

Likewise, as alternative production techniques and products become more credible and economically attractive, they are adopted by large-scale commercial producers and standardized through volume contracts and vertical coordination, if not integration. As Kirschenmann et al. (1993, p. 19) have observed: "Investment bankers from America's largest firms now prowl organic trade shows eager to incorporate emerging organic manufacturers into larger food multinational or venture capital driven marketing plays." Stated differently, agribusiness has shown itself fully capable of adopting environmentally respectable, even organic, methods and products when they can be privatized or when not adopting them proves unprofitable. Given the current structure of the industry, smaller, alternative farmers will not find any long-term economic security within so-called free-market competition.

If producing organic products for specialty markets is not a reliable way to make a living, is it nevertheless a responsible way to produce good food? To answer "yes" would be to argue that what is good for the environment is good for society at large. Can we really work toward sustainability without simultaneously addressing deep and pervasive social, economic and political inequities? This is a major debate within the sustainable agriculture and sustainable development literature. It alerts us to two troubling issues that have received only limited attention in alternative agriculture in the U.S. First, why should only those individuals with deep pockets have access to good food? Second, why should good food be a "specialty item" something relegated to a market niche in the first place?

Certainly, a partial answer hinges on the production paradigm that many alternative producers continue to share, and are encouraged to share, with the agriculture/food industry as a whole. Michigan's Assistant Director of Agriculture, for instance, publicly advised the state's organic producers to pursue niche markets. In this paradigm, food is a market commodity. It is viewed as a product grown to satisfy a niche within the now global marketplace. Its primary purpose is to feed capital and expand profit. Only secondarily is it grown to feed people and expand their creative capabilities. Given this orientation, human relationships are simplified to a single dimension (their potential for market-based consumption) and the value of a relationship equates with the value of a market exchange. As one midwestern organic farmer unwittingly summarized, "Everybody needs business cards" and don't forget to "always treat friends and neighbors as potential customers."

Those who can't (or won't) interact along this purely "practical" dimension can easily be dismissed and devalued. Such a perspective makes it possible to ignore the

American Journal of Alternative Agriculture 
rights of significant portions of the population - the poor, the hungry, agricultural labor, women, racial and ethnic minorities. It also dehumanizes or sanitizes what otherwise would be complex, "messy" and meaningful human and ethical considerations. As a result, it is possible to sidestep or define out of existence issues of public rights, public access, public participation and accountability. It becomes both possible and desirable to replace the "common good" with a cost-benefit analysis.

This prevalent mindset is still wedded to a system that is monocultural (in all senses of the term). And it will have the same stifling and wasteful results, whether they are obtained organically or conventionally. Within this mindset, the human experience increasingly is commoditized and torn apart, with each surviving bit molded to fit a market exchange. We can, however, envision an alternative system in which economics - production, utilization, trade is (re)embedded in culture and (re)integrated into all the activities that define oneself, one's relationships to others, and one's social and physical place in the universe. The former requires us to ask, "What can I grow that will make me money?" and "How much can I charge for my product?" The latter permits us to ask, "What can I grow that will allow more people to eat better and become more directly involved in the food system?" and "How little do I need to farm in a socially and environmentally regenerative manner?"

This second set of questions uses organic or low-input production practices and technologies to address the inequities, the exploitive relationships, and the dependencies that conventional agriculture has benefitted from but has ignored. These questions imply an agriculture reunited with its social context. As Henderson (1992, p. 35) has expressed it, "Organic agriculture can never be agri-business as usual. The strength of the organic movement lies in its decentralization and regional orientation. The foundation of our growing system is stewardship of the land, long-term sustainable relationships with soil organisms, animals and our fellow human beings."

Proceeding from this alternative paradigm does not mean that producers must forgo being practical or making a living. Quite the contrary: as Kneen (1993) has noted, it means being paid fairly for the work that we do rather than defining what we do solely in terms of making money. It means directing more emphasis inward toward domestic food security than outward toward volume production and expansion of export markets. This will require that producers and eaters share the risks, rewards and responsibilities of natural resource use, food production and distribution at local and regional levels. Nonproducers will need to know where their farmers are and where they are "coming from." They will need to know how farm practices affect the health of the environment and the quality of food it supports. Farmers, in turn, will need to know where there is local hunger and where it's "coming from." Likewise, they will need to know how the lack of food and resource equity affects the health of the surrounding community and the quality of life it supports.

This "connectedness" emerges as we forge new relationships not around commodity markets but around a more locally responsive food system. Diverse institutions like community supported agriculture, producer-nonproducer cooperatives, urban gardens, farmers' markets, community land trusts, and food policy councils are components of such a system. Each gives expression to the inherent relationship between good food, good farming and community building. And "community," as Ebenreck (1992, p. 3) has so elegantly written, "is our name for the living, heartfelt and truly sustaining, mutually empowering, networks of relationships" that are basic to our species.

We can use our knowledge of organic and alternative methods of farming as a tool to decentralize and democratize our food system. This knowledge and the philosophy that underlies it constitute the collective wisdom and energy of thousands of organic and low-input farmers and activists who with little economic or institutional support have challenged conventional farming. All of us who eat, not just those who raise our food, must now extend this challenge into both the social and the economic realm of our daily lives. Otherwise, we will continue to lose the opportunities and choices that new agroenvironmental relationships can offer. They will be submerged beneath the dominant market paradigm. And, that, as niche-oriented production indicates, is no alternative at all.

\section{References}

1. Ebenreck, S. 1992. A sense of place: Nature and significance of community. In Alternative Farming Systems and Rural Communities: Exploring the Connections. Institute for Alternative Agriculture, Greenbelt, Maryland. pp. 1-8.

2. Henderson, E. 1992. Open letter to the organic community. Organic Food Matters 6(Fall/Winter):5,35.

3. Kirschenmann, F., G. Kahn, and A. Ferguson. 1993. Towards a sustainable, organic food marketing system. Organic Farmer 4(Spring): 19-20.

4. Kneen, B. 1993. From Land to Mouth: Understanding the Food System (A Second Helping). NC Press Limited, Toronto, Canada.

\section{Large Hog Producers May "Cripple" lowa Family Farms, Paper Reports}

Large corporate hog producers in Iowa are not only "destroying the quality of [Iowans]' lives with intolerable odors and the threat of groundwater contamination," but also threatening eventually to "cripple the traditional backbone of Iowa agriculture, the family farm," according to a recent front-page article in The Washington Post. With large producers "invading the state," constructing huge facilities that "yield with assembly-line efficiency growing amounts of leaner pork...it is not just the air and water that are threatened, critics argue, but a way of life." Large corporate producers have been responsible for substantial gains made in North Carolina's pork production, and were also responsible for transforming the poultry industry, shifting its center from Iowa to Arkansas, Maryland, and Virginia. A government task force has been set up to study the environmental issues at stake, and when the state legislature convenes in January, several measures will probably be introduced to restrict the growth of large hog farms, according to the article. Iowa currently accounts for 25 percent of the nation's pork production. 